Reprod. Nutr. Dévelop., 1987, 27 (2 B), 547-553.

\title{
Plasma concentrations of growth hormone and somatomedin C in dwarf and normal chickens
}

\author{
L. M. HUYBRECHTS, E. R. KÜHN, E. DECUYPERE $\left({ }^{*}\right)$, P. MÉRAT $\left({ }^{* *}\right)$, \\ C. G. SCANES $(* * *)$
}

Laboratory of Comparative Endocrinology, K.U.L. Naamsestraat 61, B-3000 Leuven, Belgium.

(*) Laboratory of Ecophysiology of Domestic Animals, K.U.L., B-3030 Leuven, Belgium.

(**) Laboratoire de Génétique Factorielle, I.N.R.A., 78350 Jouy-en-Josas, France.

(***) Department of Animal Sciences, Rutgers, The State University, New Brunswick, NY 08903 U.S.A.

Summary. Sex-linked dwarf chicks, offspring from the mating of heterozygous sires with dwarf females, were used in this study. On days 18 and 20 of incubation, plasma concentrations of growth hormone $(\mathrm{GH})$ and somatomedin $\mathrm{C}(\mathrm{Sm}-\mathrm{C})$ did not differ between normal chicks and those of the dw-dwdw genotype. After hatching, Sm-C concentrations in normal chicks remained comparable to the embryo values for up to 1 week, but those in dwarf chicks were lower. After 3 weeks $\mathrm{Sm}-\mathrm{C}$ increased greatly in the controls, whereas in dawrf birds it was far less pronounced up to 18 weeks of age and only increased to control levels on week 12. $\mathrm{GH}$ was low during incubation and increased sharply after hatching in normal and dwarf chicks. After 3 weeks and up to 18 weeks, GH levels were higher in dwarf chicks, except at week 12 when they decreased to control concentrations.

\section{Introduction.}

The patterns of growth hormone $(\mathrm{GH})$ and somatomedin $\mathrm{C}(\mathrm{Sm}-\mathrm{C})$ levels during growth in chicks have been studied extensively. Special attention has been paid to hormonal differences occurring between growing normal and dwarf chickens.

Hoshino et al. (1982) observed no differences in GH levels between normal and dwarf chicks from 7 to 30 weeks of age. Plasma $\mathrm{Sm}$-C activity on the other hand was significantly depressed in dwarf birds compared to normal ones. Similar results were obtained by Scanes et al. (1983) for GH levels and by Huybrechts et al. (1985c) for $\mathrm{Sm}-\mathrm{C}$ levels in both normal and dwarf birds.

The effect of a GH secretagogue on GH secretion in both types of birds has also been investigated. Human pancreatic growth hormone releasing factor (hpGRF) has been reported to stimulate GH secretion in birds (Harvey and Scanes, 1984). In posthatch chicks this response is higher in dwarf chickens (Harvey, Scanes and Marsh, 1984 ; Huybrechts et al., 1985a). TRH, the other GH secretagogue, has also been reported to induce a higher response in dwarf birds (Harvey and Scanes, 1984 ; Hoshino et al., 1984 ; Huybrechts et al., 1985b). 
In all these studies, the dwarf birds used were defined populations, separated from the control birds for at least several generations. In order to overcome possible differences in hormonal patterns caused by factors other than the sexlinked dwarf gene, we used offspring from the mating of heterozygous sires with dwarf females in this study (Demarne et al., 1984).

\section{Material and methods.}

The eggs used in this study came from the mating of heterozygous sires with dwarf females (Demarne et al., 1984). To make it easier to distinguish between normal and dwarf chick embryos or early posthatch chicks, we used a linkage between the dwarf gene and the gold gene for feather color (table 1). The eggs were incubated at $37.5^{\circ} \mathrm{C}$ in a forced-draught incubator. After hatching, the birds were maintained under a long-day photoperiod of 16 hours of light and 8 hours of darkness (16 L : $8 \mathrm{D}$ ) ; food and water were available ad libitum prior to experimentation.

TABLE 1

Mating of heterozygous sires (Dwdw) with dwarf females (dw-). The dwarf gene (dw) was linked with the gold (s) gene for feather color and the normal (DW) gene was linked with the silver (S) allelle.

LINKAGE OF DWARF AND COLOR GENE

(phenotype within parentheses)

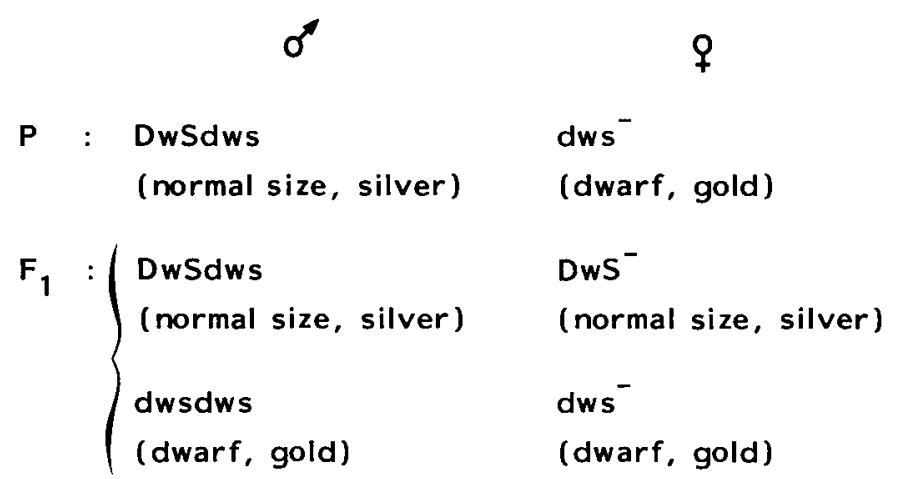

Using heparine as an anticoagulant, blood samples were taken by cardiac puncture during embryogenesis, by decapitation at days 1 and 5 posthatch, and through the brachial vein of fed birds at all the other ages studied ( $n=7$ for all ages and for each genotype).

The plasma was separated and stored at $-20^{\circ} \mathrm{C}$ until assay. GH concentration was measured using an homologous radioimmunoassay (Harvey and Scanes, 1977). Sm-C activity was determined using an heterologous radioimmunoassay (Huybrechts et al., 1985c). Statistical differences were calculated by Student's ttest or analysis of variance within a genotype and across times when appropriate. 


\section{Results.}

Posthatch relative growth (RG) of both normal and dwarf chicks, expressed as the difference in body weight at the beginning and end of the week divided by body weight and the number of days between two weighings, is shown in figure 1. There was a difference in RG in the first 6 to 8 weeks since the normal birds had a higher RG. After 6 to 8 weeks, both groups showed the same RG, but at the age of 18 weeks the body weight of dwarf chicks was $30 \%$ less than that of the controls. At this age, male dwarf chicks weighed $2010 \pm 170 \mathrm{~g}(\mathrm{n}=7) \mathrm{com}$ pared to $2790 \pm 146 \mathrm{~g}(\mathrm{n}=11)$ for control males, whereas dwarf females weighed $1682 \pm 78 \mathrm{~g}(\mathrm{n}=11)$ and the controls $2254 \pm 88 \mathrm{~g}(\mathrm{n}=12)$.

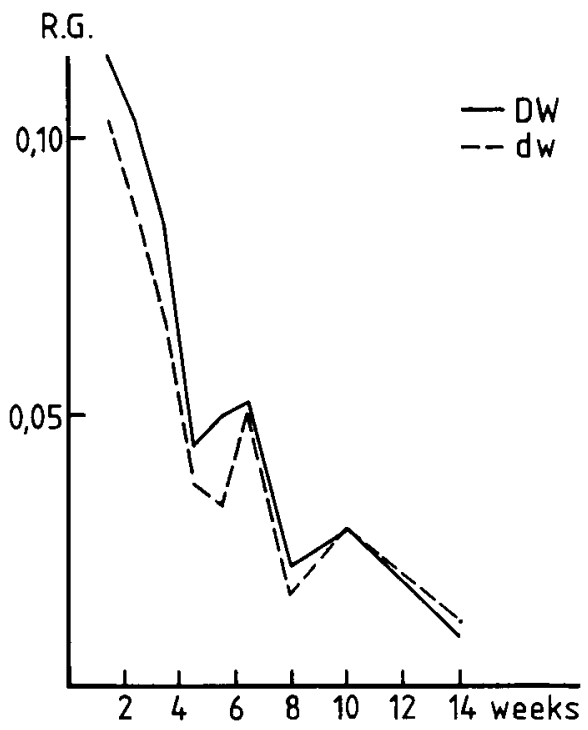

FIG. 1. - Relative growth of (Dw) and (dw) chickens post-hatching between 2 and 14 weeks of posthatching age. __ control birds ; ------- dwarf birds.

Plasma concentrations of $\mathrm{GH}$ and $\mathrm{Sm}-\mathrm{C}$ activity are shown in figures 2 and 3. During the prenatal period (days 18 and 20 of incubation), no differences in $\mathrm{GH}$ or $\mathrm{Sm}-\mathrm{C}$ levels were found between normal and dwarf birds. The $\mathrm{GH}$ levels increased sharply in both groups after hatching. Between 3 weeks and 18 weeks of age, dwarf chicks had higher GH levels than the controls, except at 12 weeks when a decrease occurred. $\mathrm{Sm}-\mathrm{C}$ activity, which was also identical before hatching, became statistically different immediately after hatching with the dwarf birds showing lower $\mathrm{Sm}-\mathrm{C}$ activity ; this activity in dwarf birds remained low up to 18 weeks of age, except at 12 weeks when an increase occurred.

Table 2 shows the correlation coefficients between RG and $\mathrm{GH}$ and $\mathrm{Sm}-\mathrm{C}$ levels from 3 to 9 weeks. In control birds there was a positive correlation $(P<0.01)$ between the $R G$ and $G H$ levels. In dwarf birds there was a distinct 


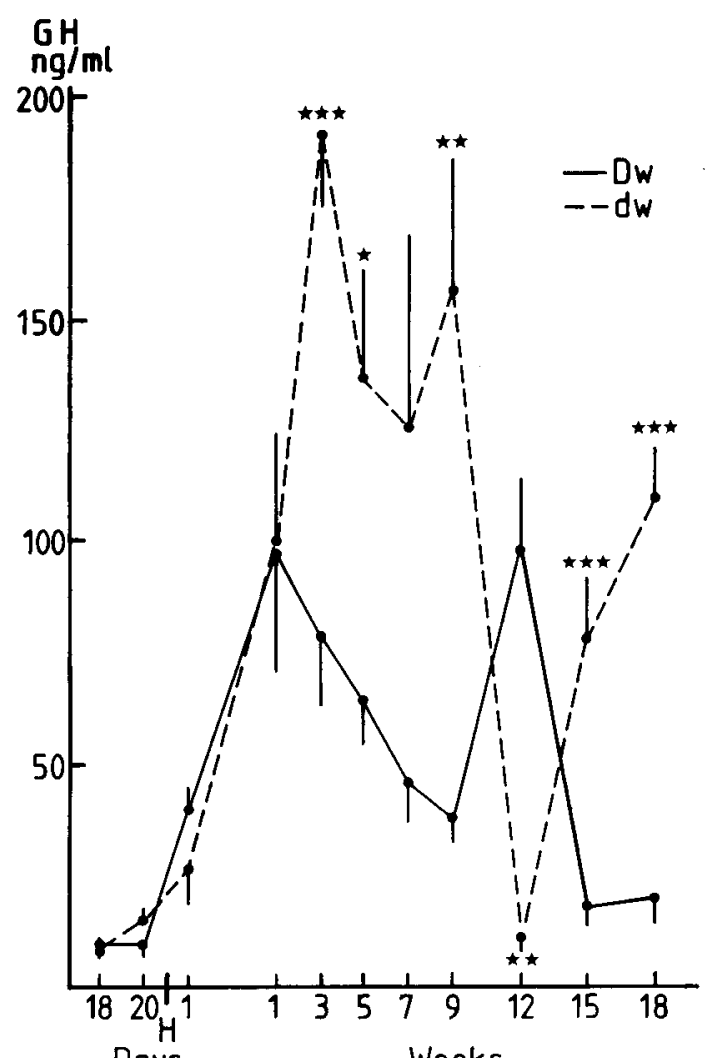

Days
Weeks

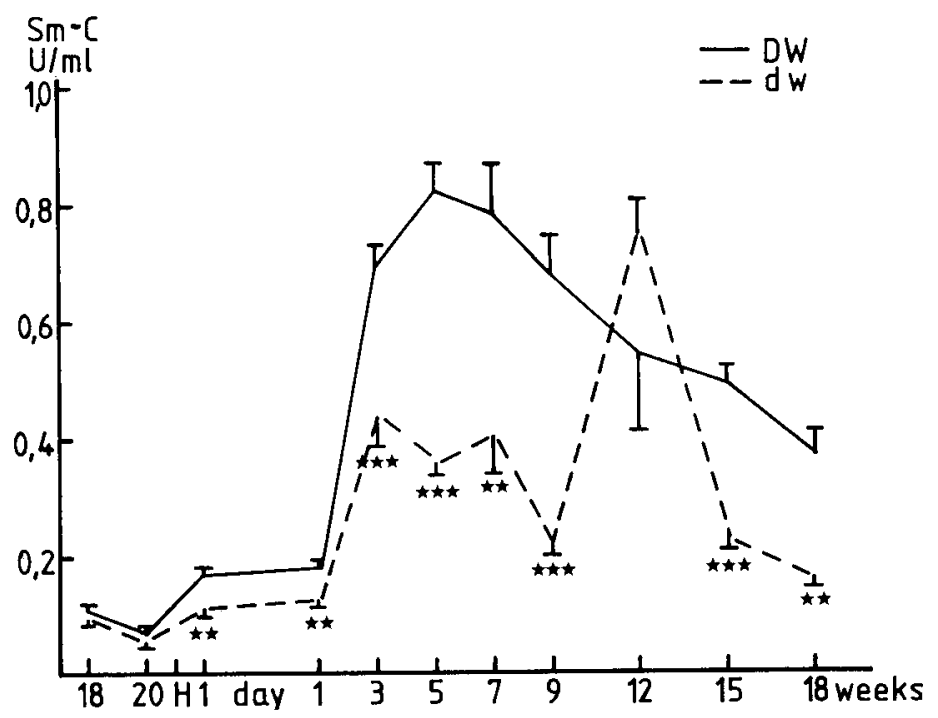

FIG. 3. - Plasma concentrations of Sm-C in Dw and $d w$ chickens. Mean \pm SEM, ${ }^{* *} \mathrm{P}<0.01{ }^{* * *} \mathrm{P}<0.001$, Student's $\mathrm{t}$-test compared to control birds $(\mathrm{n}=8-10$ ). control birds ; -...-.. dwarf birds.

FIG. 2. - Plasma concentrations of GH in $D w$ and $d w$ chickens. Mean \pm SEM， ${ }^{* P}<0.05{ }^{* * P}<0.01$ ${ }^{* * *} P<0.001$, Student's t-test compared to control birds (n $=8$ 10). — control birds ; dwarf birds. 
correlation $(P<0.001)$ between $S m-C$ activity and the $R G$, but there was no correlation between the $R G$ and $\mathrm{GH}$.

TABLE 2

Correlation coefficients between R.G. and plasma concentrations of $G H$ and $S m-C$ in (Dw) and (dw) chickens.
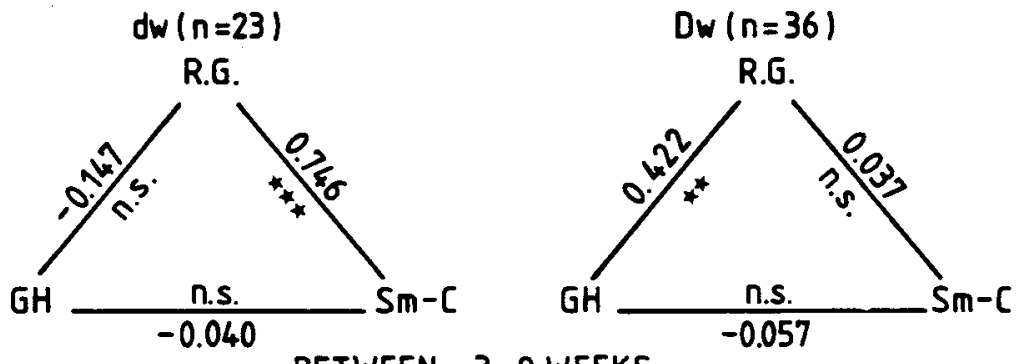

BETWEEN 3-9 WEEKS

\section{Discussion.}

The results on $\mathrm{GH}$ levels and $\mathrm{Sm}-\mathrm{C}$ activity during growth are in agreement with previous reports (Hoshino et al., 1982 ; Scanes et al., 1983). The differences in plasma $\mathrm{GH}$ concentration between normal and dwarf birds were more pronounced than in previous reports. Scanes et al. (1983) found significant differences only at weeks 12,15 and 18 . However, the same distinct differences at all the ages studied ( 0 to 6 weeks) have been found in broilers following an experimental design similar to the one used in the present study (Stewart et al., 1984). The lack of differences in both $\mathrm{GH}$ and $\mathrm{Sm}-\mathrm{C}$ levels before hatching indicates that some maturation has to take place before differences between normal and dwarf chicks become evident.

The positive correlation between the $\mathrm{RG}$ and plasma $\mathrm{GH}$ concentration in normal birds was in agreement with the previous findings of Harvey et al. (1979). However, it should be stressed that the relationship between growth and $\mathrm{GH}$ levels is not always consistent (Scanes and Lauterio, 1984).

The difference in plasma $\mathrm{GH}$ concentrations between dwarfs and controls may be the result of low circulating levels of $\mathrm{Sm}-\mathrm{C}$; there is some evidence of a negative feedback at the hypophyseal level (Scanes et al., 1986), but also of lower plasma $T_{3}$ concentrations in dwarfs affecting $\mathrm{TRH}$ at hypothalamic levels (Harvey and Scanes, 1984) or GH at the hypophyseal level (Harvey, 1983). On the other hand, a lower rate of peripheral growth hormone degradation in dwarfs cannot be ruled out.

The higher $\mathrm{GH}$ levels observed in dwarf chickens may also be related to the fact that, after hatching, both hpGRF and TRH stimulate $\mathrm{GH}$ secretion in a similar way, with the dwarfs reacting more and longer to a single injection (Harvey et al., 1984 ; Hoshino et al., 1984 ; Harvey and Scanes, 1984). These observations have 
been confirmed using similar animals as in the present study (Huybrechts et al., 1985a, 1985b).

The posthatching effects of both TRH and hpGRF (Huybrechts et al., 1985a, 1985b) may indicate increased pituitary responsiveness in dwarfs because of a possibly higher pituitary $\mathrm{GH}$ content since a release of pituitary $\mathrm{GH}$ stores is an acute response to a $\mathrm{GH}$ secretagogue (Vale et al., 1983).

The lower plasma Sm-C concentrations in dwarfs may be related to lower $T_{3}$ levels, which could result from a lack of $\mathrm{GH}$ for stimulating hepatic $5^{\prime}$ monodeiodinase activity in dwarfs (Kühn et al., 1986).

$12^{e}$ Réunion du groupe Développement I.N.R.A., Montpellier, 28-30 mai 1986.

Acknowledgements. - We are indebted to Dr L. E. Underwood and the National Pituitary Program for the $\mathrm{Sm}-\mathrm{C}$ radioimmunoassay reagents.

Résumé. Concentrations plasmatiques de l'hormone de croissance et de somatomédine $C$ chez les poussins nains et normaux pendant la croissance.

Dans cette étude on a utilisé les poussins nains originaires de croisements entre des mâles hétérozygotes et des femelles naines homozygotes (dw-) (Dwdw).

Aux $18^{e}$ et $20^{e}$ jours de l'incubation les concentrations plasmatiques de l'hormone de croissance $(\mathrm{GH})$ et de somatomédine $\mathrm{C}(\mathrm{Sm}-\mathrm{C})$ étaient similaires chez les poussins normaux et nains (génotype $d w$ - ou dwdw). Après l'éclosion les niveaux de $S m-C$ des animaux de contrôle étaient comparables aux valeurs embryonnaires jusqu'à l'âge d'une semaine, mais les $\mathrm{Sm}-\mathrm{C}$ niveaux des poussins nains étaient alors inférieurs aux valeurs normales. Après 3 semaines la concentration de $\mathrm{Sm}-\mathrm{C}$ augmentait fortement avec l'âge des poussins normaux jusqu'à 18 semaines tandis que l'augmentation était beaucoup moins prononcée chez les nains, à l'exception des valeurs à 12 semaines où il n'y avait pas de différences entre les deux lignées. Pendant l'incubation, les niveaux de I'hormone de croissance (GH) étaient à niveau bas ; ils augmentaient nettement après l'éclosion aussi bien chez les poussins normaux que chez les nains. Entre 3 et 18 semaines les niveaux circulants de $\mathrm{GH}$ étaient plus élevés chez les nains à l'exception des valeurs à 12 semaines, où il n'y avait de nouveau pas de différences entre les deux génotypes.

\section{Références}

DEMARNE Y., MERAT P., PIHET A., 1984. Composition des lipides de l'œuf chez des poules Leghorn normales et naines. Génét. Sél. Evol., 16, 211-220.

HARVEY S., 1983. Thyroid hormones inhibit GH secretion in the domestic fowl. J. Endocr., 96 , 329-334.

HARVEY S., SCANES C. G., 1977. Purification and radioimmunoassay of chicken growth hormone. J. Endocr., 73, 321-329.

HARVEY S., SCANES C. G., 1984. Comparative stimulation of growth secretion in anaesthetized chickens by human pancreatic growth hormone releasing factor (hpGRF) and thyrotrophinreleasing hormone (TRH). Neuroendocrinology, 39, 314-320.

HARVEY S., SCANES C. G., CHADWICK A., BOLTON N. J., 1979. Growth hormone and prolactin secretion in growing domestic fowl: Influence of sex and breed. Br. Poult. Sci., 20, 9-17.

HARVEY S., SCANES C. G., MARSH J. A., 1984. Stimulation of growth hormone secretion in dwarf chickens by thyrotrophin-releasing hormone (TRH) or human pancreatic growth hormone releasing factor (hpGRF). Gen. comp. Endocrinol, 55, 493-497. 
HOSHINO S., SUZUKI M., WAKITA M., KOBAYASHI Y., 1984. Stimulation of growth hormone release in dwarf and normal chickens by thyrotrophin-releasing hormone (TRH) or human pancreatic growth hormone releasing factor (hpGRF). J. Steroid Biochem., 20, 1550.

HOSHINO S., WAKITA M., SUZUKI M., YAMAMOTO K., 1982. Changes in a somatomedin-like factor and immunoassayable growth hormone during growth of normal and dwarf pullets and cockerels. Poult. Sci., 61, 777-784.

HUYBRECHTS L. M., DECUYPERE E., KÜHN E. R., LAUTERIO T. J., SCANES C. G., MONGIN P., 1985a. Growth hormone secretory response to thyrotropin-releasing hormone in normal and dwarf chickens. Reprod. Nutr. Dévelop., 25, 641-645.

HUYBRECHTS L. M., DECUYPERE E., SCANES C. G., CALLEWAERT P., PEYS E., KÜHN E. R., 1985b. Human pancreatic growth hormone releasing factor stimulates growth hormone secretion in perinatal dwarf and control chickens. Horm. Metabol. Res., 17, 690-691.

HUYBRECHTS L. M., KING D. B., LAUTERIO T. J., MARSH J., SCANES C. G., 1985c. Plasma concentrations of somatomedin $C$ in hypophysectomized dwarf and intact growing domestic fowl as determined by heterologous radioimmunoassay. J. Endocr., 104, 233-239.

KÜHN E. R., HUYBRECHTS L. M., DECUYPERE E., MÉRAT P., 1986. Endocrinological effects of the sex-linked dwarf gene: III. Prolactin and growth hormone fail to increase the liver $\mathrm{T}_{4}-5^{\prime}$-monodeiodinase activity in the sex-linked dwarf chick embryo. Proc. 7th Eur. Poultry Conf., Paris, August 24-28.

SCANES C. G., CAMPBELL R., HARVEY S., KING D., MALAMED S., PEREZ F., 1986. Growth hormone in birds: A comparative perspective, 115-136. In Comparative endocrinology: developments and directions, Ed. Alan R. Liss, Inc., New York.

SCANES C. G., LAUTERIO T. J., 1984. Growth hormone: its physiology and control. J. exp. Zool., 232, 443-452.

SCANES C. G., MARSH J., DECUYPERE E., RUDAS P., 1983. Abnormalities in the plasma concentrations of thyroxine, tri-iodothyronine and growth hormone in sex-linked dwarf and autosomal dwarf White Leghorn domestic fowl. J. Endocr., 97, 127-135.

STEWART P. A., WASHBURN K. W., MARKS H. L., 1984. Effect of the dw gene on growth, plasma hormone concentrations and hepatic enzyme activity in a randambred population of chickens. Growth, 48, 59-73.

VALE W., VAUGHAN J., YAMAMOTO G., SPIESS J., RIVIER J., 1983. Effects of synthetic human pancreatic (tumor) $\mathrm{GH}$ releasing factor and somatostatin, triiodothyronine and dexamethasone on $\mathrm{GH}$ secretion in vitro. Endocrinology, 112, 1553-1555. 